1975

\title{
An Assessment of Archaeological Resources in Portions of Starr County, Texas
}

Parker Nunley

Thomas R. Hester

Center for Archaeological Research

Follow this and additional works at: https://scholarworks.sfasu.edu/ita

Part of the American Material Culture Commons, Archaeological Anthropology Commons, Environmental Studies Commons, Other American Studies Commons, Other Arts and Humanities Commons, Other History of Art, Architecture, and Archaeology Commons, and the United States History Commons

Tell us how this article helped you.

This Article is brought to you for free and open access by the Center for Regional Heritage Research at SFA ScholarWorks. It has been accepted for inclusion in Index of Texas Archaeology: Open Access Gray Literature from the Lone Star State by an authorized editor of SFA ScholarWorks. For more information, please contact cdsscholarworks@sfasu.edu. 
An Assessment of Archaeological Resources in Portions of Starr County, Texas

Creative Commons License

(C) $(1) \Theta$

This work is licensed under a Creative Commons Attribution-NonCommercial 4.0 International License 


\title{
AN ASSESSMENT OF ARCHAEOLOGICAL RESOURCES IN PORTIONS OF STARR COUNTY, TEXAS
}

\author{
Parker Nanley \\ and \\ Thomas R. Hester
}

Center for Archaeological Research The University of Texas at San Antonio Archaeological Survey Report, No.7

1975

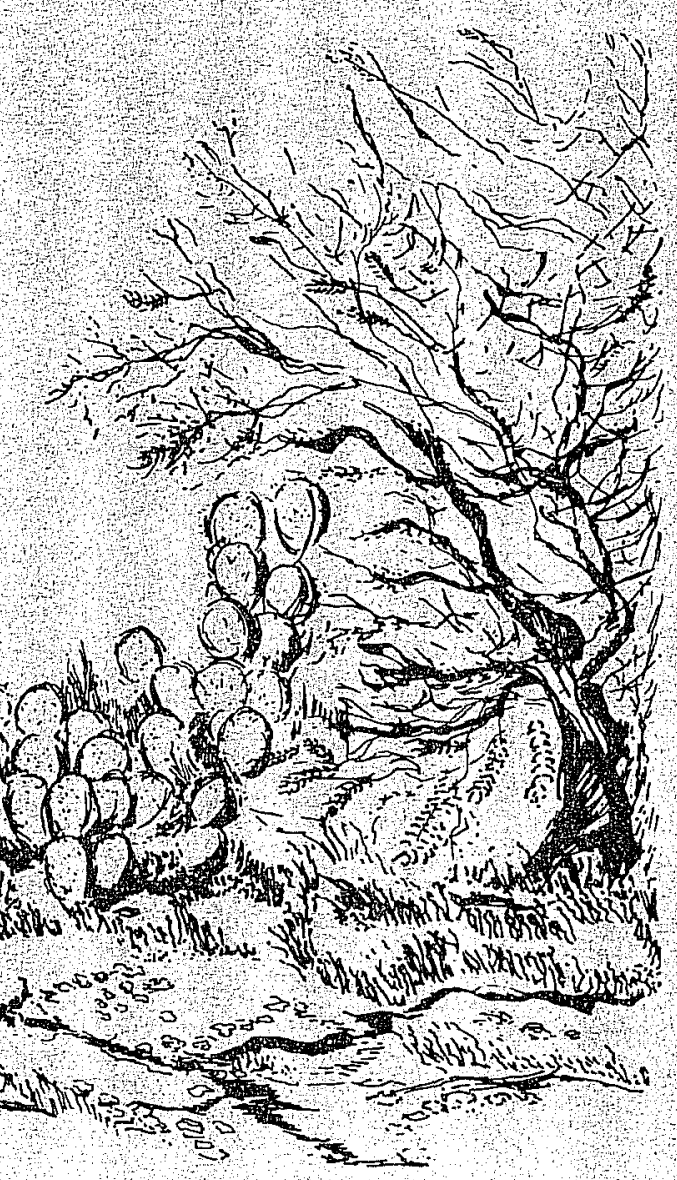

UTSA - Center for

Archaeological Research 
THE CENTER FOR ARCHAEOLOGICAL RESEARCH

Division of Social Sciences

The University of Texas at San Antonio

Thomas R. Hester, Director

Archaeological Survey Reports

1. Assessment of Archaeological Resources in Certain Areas of the Allens Creek Watershed, Austin County, Texas. By Feris A. Bass, Jr., September, 1974

2. Assessment of Archaeological Resources in Portions of the Chocolate Creek, Little Chocolate Creek and Lynns Bayou Watershed, Victoria and Calhoun Counties, Texas. By Feris A. Bass, Jr., October, 1974

3. Archaeological Survey of Areas Proposed for Modification in the Salado Creek Watershed, Bexar County, Texas. By Thomas R. Hester, with the collaboration of Feris Bass, Jr., Anne A. Fox, Thomas C. Kelly, Mary F. Chadderdon and Edwin S. Harris, November, 1974

4. An Archaeological Survey of Portions of the Chiltipin-San Fernando Creeks Watershed, Jim Wells County, Texas. By Thomas R. Hester and Feris A. Bass, Jr., November, 1974

5. An Archaeological Survey of the Nichols Creek Channel Modification, Karnes County, Texas. By Anne Adams Fox, December, 1974

6. Archaeological Survey of Portions of the Comal River Watershed, Comal County, Texas. By Thomas R. Hester, Feris A. Bass, Jr. and Thomas C. Kelly, January, 1975

7. An Assessment of Archaeological Resources in Portions of Starr County, Texas. By Parker Nunley and Thomas R. Hester, March, 1975

Regional Studies

1. Archaeological and Historical Resources in the San Antonio-Guadalupe River Basins: A Preliminary Statement. Assembled by Thomas R. Hester, January, 1975

2. An Initial Archaeological and Historical Assessment of Three Proposed Dam Sites in Gonzales and Kendal1 Counties, Texas. By Thomas R. Hester, Thomas C. Kelly, and Feris A. Bass, Jr., February, 1975 
AN ASSESSMENT OF ARCHAEOLOGICAL RESOURCES

IN PORTIONS OF STARR COUNTY, TEXAS

Parker Nunley and Thomas R. Hester

Center for Archaeological Research The University of Texas at San Antonio Archaeological Survey Report, No. 7

1975 


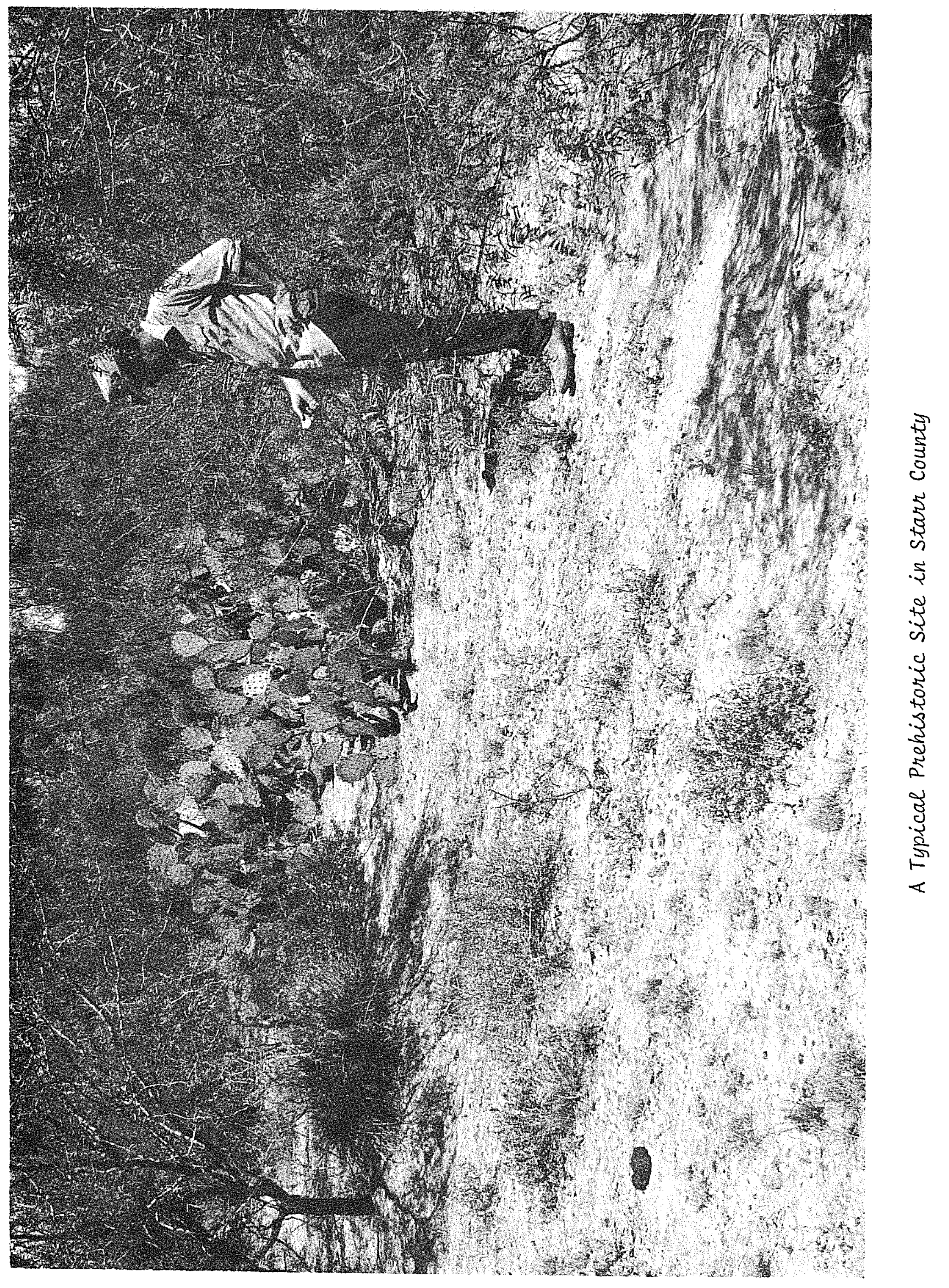




\section{ABSTRACT}

Fifty-two archaeological sites in the vicinity of nine projects proposed by the United States Department of Agriculture, Soil Conservation Service, in Starr County, Texas, are described and evaluated. It was determined that no further investigation need be made at 29 of these sites, whereas controlled collections and testing is necessary at 18 sites, and excavation is recommended at an additional five sites. 


\section{ACKNOWLEDGEMENTS}

The bulk of this study was carried out by the senior author with the assistance of students from Richland college and The University of Texas at San Antonio at the suggestion of Dr. Thomas R. Hester, Director, Center for Archaeological Research, The University of Texas at San Antonio (UTSA).

Silvestre Gonzalez, Starr County Soil Conservation District Conservationist, provided our immediate liaison with the Soil Conservation Service and local landowners. We are indebted to him for the swift and friendly support he gave to our work. We would also like to specifically thank personnel on the staff of the Soil Conservation Service projects planning division, San Marcos, Texas, for their helpfulness and courtesy.

The field work was performed under the direction of the senior author with the assistance of Don White, Jean Henderson, and Lamar Peterman, students at Richland College, Dallas, Texas; Carol E. Nunley, graduate student at Texas Woman's University; and Feris A. Bass, Jr. graduate student at The University of Texas at San Antonio. During the period of August 5 through August 23, 1974, a total of approximately 76 man-days was spent in the field. We appreciate the efforts of the field crew members and acknowledge their major contribution to the contents of this report. 
Special thanks are due Chris Blankenship and Don White of Richland College. They served as laboratory assistants, and without them the lab work could not have been completed in the time allowed.

Artifact photography is by Hubert Achor.

Typing assistance was rendered by Carol Naab. Final typing of the report at the UTSA Center for Archaeological Research was done by Kathy McCauley and Bonnie Ernest. Cover design is by Olivia Rodriguez, UTSA Office of Instructional Services. 


\section{TABLE OF CONTENTS}

Page

Frontispiece

Abstract

ii

Acknowledgements

iii

List of Figures and Tables

vi

Introduction

1

Previous Archaeological Research in the Area

6

The Sites

11

The Artifacts

65

Artifact Descriptions

70

Summary and Recommendations

93

References Cited

102

Appendix

107 
Figures

Page

1. Locations of Proposed Soil Conservation Service

12 Projects in Starr County, Texas

2. Overview of Site 41 SR 95

3. Hearth Eroding from Surface of Site 41 SR 118, Damsite 8

4. Locations of Archaeological Sites in the Damsite $1 \mathrm{~B}$ Area

5. Locations of Archaeological Sites in the Damsite 2 Area

61

6. Locations of Archaeological Sites in the Damsite 3 Area

7. Locations of Archaeological Sites in the Damsite 7 Area

8. Locations of Archaeological Sites in the Damsite 8 Area.

9. Morphologic Outlines

10. Bifaces

11. Bifaces

12. Bifaces

13. Unifaces

14. Unifaces

15. Locations of Archaeological Sites in the Damsite 6 Area

Tables

I Provenience of Artifacts, Bifaces

II Provenience of Artifacts, Bifaces 89

III Provenience of Artifacts, Unifaces 91

IV Summary of the Impact of the Proposed Modifications 99 


\section{INTRODUCTION}

This report is the culmination of research undertaken as part of the impact study of the effects of certain environmental modifications proposed by the United States Department of Agriculture, Soil Conservation Service, in Starr County, Texas. This study was initiated through a cooperative agreement between representatives of the Soil Conservation Service and Dr. Thomas $\mathrm{R}$. Hester, Director of the Center for Archaeological Research (Division of Social Sciences, College of Humanities and Social Sciences), The University of Texas at San Antonio, to provide a factual basis upon which to determine the deleterious effect, if any, the proposed modifications (floodwater retarding structures) might have on archeological resources in the area and to propose a reasonable strategy to minimize such effects.

In order to provide the most efficient use of time in the field, the following priorities were established.

Priority I: This priority was assigned to those areas most directly affected by the proposed modifications. These areas include damsites, levees, spillways, conservation pools, etc.

Priority II: This priority was assigned to all those portions of the areas to be modified falling within the 100 year flood pool. 
Priority III: This was the priority assigned to those areas adjacent to, or of other relation to the areas to be modified.

The above priorities were used to allocate use of available personnel in the field. It is estimated that approximately $90 \%$ of the primary area was actually visited. Of the remaining $10 \%$, most consists of heavily silted floodplains overgrown with dense covers of grass and brush. Although these unvisited areas possibly include a number of sites, it is not likely.

Those sites reported in areas of secondary priority are those located by intensive field investigation as well as those located through the study of topographic maps. Although it is difficult to estimate the percentage of the secondary area actually traversed in the field, a full two-thirds of the total field effort was spent in secondary areas. Much of the time spent in areas of secondary priority was directed toward spots suggested by study of topographic maps.

Field work begun August 6, 1974 and continued daily through August 22, 1974. In spite of unusually wet weather, crews were in the field a total of 15 days during this period. Average crew size was five persons, and in all, approximately 76 man-days were spent searching for sites in the field. Field work was supervised by the senior author. The areas surveyed in the field are indicated in Figure 1 and total approximately 10,000 acres (4048.5 hectares). In addition to work in the field, the Texas Archeological 
Research Laboratory, The University of Texas at Austin, was visited, and a complete and thorough search of their records for data pertinent to the present work was made. Copies of documents directly related to the present research were obtained and maps and artifact lists on file there were checked. The libraries of both Southern Methodist University and The University of Texas at Austin were consulted for documentary information concerning the location and characteristics of sites and prehistoric occupations in the area.

All sites found in the course of the present work have been recorded on standard site survey forms in use by the Center for Archaeological Research of the University of Texas at San Antonio. In addition, a daily journal was maintained and all sites were located on standard U.S.G.S. topographic maps of the $7.5^{\prime}$ series furnished by the Soil Conservation Service. Black and white photographs and $35 \mathrm{~mm}$. color slides were made at many sites. Artifacts were collected at most of the sites visited by field crews. These were placed in brown bags labeled as to site, date, and crew. When applicable, as in the case of a very large site, or a site with a particularly distinguishable feature such as a hearth, attempts were made to control the sampling of materials. This attempt turned out to be futile, however, and was abandoned midway through the field work.

Most artifacts were cleaned and catalogued in the field. Bags of artifacts were brought to Richland College, Dallas, Texas, 
where the artifacts were described and analyzed. The artifacts and copies of all documents assembled and compiled in the course of this study will, in time, be stored at the Center for Archaeological Research at UTSA. Duplicates of the records will, in addition, be sent to the Texas Archeological Research Laboratory in Austin.

Relatively few artifacts were either observed or collected during the course of this study. Three major reasons for this lack of cultural material are: (1) many of the sites have been heavily searched and collected by amateurs for many years; (2) throughout the area of the survey much of the surface has been rootplowed and seeded to bufflegrass which has subsequently grown and covered the ground. This treatment tends to obscure artifacts, especially the smaller ones which might have escaped the collectors; and (3) the areas of investigation seem to have been outside the areas of densest occupation.

One tactic employed by some workers in initial field surveys is to locate and record sites in the conventional manner while disturbing the site as little as possible. Although this tactic has definite advantages under ideal circumstances, since it leaves the archeological record relatively undisturbed, it is not a very efficient use of field time and was not employed in the field work portion of the current work.

Since many of the sites visited in the course of the current study are relatively inaccessible and subject to continued damage 
by erosion, relic collecting, and other factors, artifacts were collected from the surface of most sites. It was hoped that enough artifactual material could be gathered to permit analysis and thereby add to the resolution of particular problems while suggesting certain new ones.

There was reason to expect, for example, that data from controlled surface collections could lend information concerning settlement patterns and differentiation of various sociocultural units as proposed by Nunley (1971a). Such controlled collecting was attempted during the early stages of the field work, but was soon abandoned as inappropriate and inefficient under the pressing circumstances of time and manpower. Most of the collections were thereby made A.C.P.-- "at the collector's preference". Most of the fieldcrew were instructed to collect all the obvious tools and tool fragments and a sampling of the debris and debitage. This method of sampling, while not yielding collections amenable to comprehensive statistical models (such as cumulative graphs), is able to provide a reliable basis for percentage comparison within classes between sites. Unfortunately, too few artifacts were collected for even this type of comparative analysis. The physiographic/environmental setting of the Starr County region has recently been outlined in two publications (Soil Conservation Service 1972; Nunley 1971a) whose areas of interest bracket the present report and are not repeated here. 
PREVIOUS ARCHAEOLOGICAL RESEARCH IN THE AREA

General Background

Only during the past decade has there been sustained

archaeological research in southern Texas. In earlier years, most work had been done along the south Texas coast (Anderson 1932; see a summary in Campbel1 1960), with only scattered reports from the interior areas (e.g., Sellards 1940; Weir 1956; Evans 1941). A very general synthesis of the area's prehistory was offered by E. B. Sayles (1935), in which he placed south Texas in his "Coahuiltecan Branch". A more elaborate summary statement on "Southwest Texas" was published by Suhm, Krieger and Jelks (1954: p. 134-143). Most of their information was derived from recently concluded salvage investigations at Falcon Reservoir, and the two cultural units proposed by Suhm, Krieger and Jelks, the Falcon and Meir foci, were related primarily to the Falcon area.

Since 1960, archaeological investigations in southern Texas have intensified and publications dealing with its prehistory have proliferated. Many of the published works have been descriptive in nature, designed to record the varied cultural remains of the region (cf. Hester, White and White, 1969). In addition, there have been reports of regional and reservoir basin surveys (Nunley and Hester 1966; Wakefield 1969; Hester and Bass 1974; Shafer and Baxter 1975), and there have been studies of prehistoric technologies (Hester and Hill 1971; Hester in press). Short syntheses of the past decade's activities have been published (Hester, White and White 1969:p. 158-164; 
Hester 1974: 18-19), but a major summary (Hester 1971) has not been published, although it has been widely circulated to scholars working in the area.

All of this research has served to describe archaeological sites and artifacts in the area, to analyze local technologies, to examine aspects of subsistence, and settlement, (cf. Hester and Hill 1973) and to outline those problems needing further research.

One of the major problems of south Texas prehistory remains the lack of a firm chronology. Thus, we can provide here only a bare and quite tentative, framework for ordering the cultural remains.

There is substantial evidence, in the form of such distinctive projectile point styles as Clovis, Folsom, Plainview, Golondrina, Scottsbluff and others, to indicate the presence of Paleo-Indian occupations during the terminal Pleistocene, roughly 9200-6000 B.C. Following the end of the Pleistocene, and continuing for the next several thousand years, we have Archaic occupations in the region. It is from this inadequately defined period that the bulk of archaeological remains in south Texas are derived. There are numerous sites and abundant 1ithic materials, (dart points and other chipped stone implements, ground stone artifacts and lithic waste) attributable to hunting and gathering peoples inhabiting the region between $6000 \mathrm{~B} . \mathrm{C}$ 。 and A.D. 1200. Beginning around A.D. 1200 or somewhat 1ater, the regional cultural inventory is modified by the introduction of the bow and arrow (represented by tiny arrow points of various styles), certain new lithic tool forms, and in some areas, bone-tempered ceramics 
(Hester and Hill 1971). Radiocarbon evidence reported by Hill and Hester (1973) suggests that this Late Prehistoric ("Neo-American")

era continued in southern Texas as late as A.D. 1700 without recognizable modification by intruding European culture.

At the time of historic contact, early European explorers report that southern Texas was inhabited by a myriad of small semi-nomadic hunting and gathering groups, apparently the descendents of populations who had lived in the area for millenia. Most of these groups are presumed to have shared a common language, known as "Coahuiltecan", and thus these historic peoples have been identified with that term in the ethnohistoric 1iterature (cf. Ruecking 1955; Newcomb 1961). It has become increasingly evident to present-day ethnohistorians and archaeologists that many differences, both linguistic and cultural, existed among these groups, and that it is meaningless to lump them all under the "Coahuiltecan" label (cf. Nunley 1971b).

The native peoples were soon eliminated through a combination of introduced diseases, missionization, and by the process of assimilation with the growing Spanish populations. In the 18th and 19 th centuries, the void created by their disappearance was partially filled by intrusive Plains groups, first by the Lipan Apache, and subsquently by Comanche and smaller, displaced tribes. One example of the extent of Comanche presence in the area is provided by Vigness (1955; see also Faulk 1969) who documents raids by Comanches as far south as Laredo and Matamoros in the $1830^{\prime} \mathrm{s}$. 


\section{Starr County}

Although some professional work was done in the vicinity of Falcon Reservoir in the early 1950's (Cason 1952; Hartle and Stephenson 1951; Hughes n.d.; Krieger and Hughes 1950), the bulk of archaeological work in Starr County has been performed by amateur archaeologists and artifact collectors. For the last 50 years, local residents have intensively collected artifacts from the surface of sites along the Arroyo los Olmos and other streams in Starr County. Most of these collections were undocumented at the time they were made, and many have subsequently become scattered or 1ost. A few collections have been reported (i.e., Newton 1968; Weir 1956), but these reports are sketchy and of limited value here. In addition to these, several sites have been reported by recent professional activity (Weir n.d.) for a grand total of some 80 archaeological sites reported from Starr County previous to the present work.

The vast majority of the previously known sites were concentrated along the Arroyo los 0lmos for a distance of some 25 kilometers downstream from the village of E1 Sauz. The reason for this concentration of sites might have been thought to reflect on the peculiar habits of such collectors as chose to report their collections, except the present work has confirmed that the area in question apparently sustained the heaviest prehistoric populations in Starr County. The reasons for this concentration of occupation in prehistoric times are not now known, but their discovery should certainly be a major goal for future archaeological work in the area. 
Generalizations concerning the prehistory of the study area, the proposed Falcon and Meir foci, were alluded to earlier in this section. They are derived from the McKern Taxonomic System (McKern 1939) via the Kriegerian type concept (Krieger 1944, 1956). The inadequacy of these generalizations has been made clear in a recent paper (Nunley 1971b) and will not be repeated here. Let it suffice to say that there are in print no valid general statements concerning the prehistory of Starr County. There is no clear evidence concerning the date of duration of occupation, subsistence, technology, or even settlement pattern. All these are questions which must be resolved by future work. 
THE SITES

Site descriptions in this section follow the format below:

\section{Site Designation}

The site designation follows the trinomial convention in which the first number, 41, represents Texas; the two letters, SR, denote Starr County; and the last number designates a specific site.

Location: Locational data are given to place the site in general geographic and environmental context. Precise description of exact location is here avoided to forestall improper use of such information.

Damsite: Designates which of the following Soil Conservation Service projects affects the site in question (Figure 1): Damsite 1B - Located across Arroyo los 01mos at a point just west of the village of EI Sauz. Proposed emergency spillway elevation: $292.0 \mathrm{ft}(89.0 \mathrm{~m})$

Damsite 2 - Located in uplands of northwest Starr County. Proposed emergency spillway elevation: $350.0 \mathrm{ft}(106.7 \mathrm{~m})$ Damsite 3 - Located in northeast central Starr County. Proposed emergency spillway elevation: $435.5 \mathrm{ft}(132.7 \mathrm{~m})$ Damsite 4b - Located in the uplands of northeast central Starr County. Emergency spillway elevation: $434.0 \mathrm{ft}(132.3 \mathrm{~m})$ 
This page has been

redacted because it

contains restricted

information. 
Damsite 6 - Located on a tributary of Arroyo los 01mos at

a point several kilometers downstream from the village of

E1 Sauz. Proposed emergency spillway elevation: $280.0 \mathrm{ft}$ $(85.3 \mathrm{~m})$

Damsite 7 - Located just east of Arroyo los 0lmos at a point severa1 kilometers north of Rio Grande City. Proposed emergency spillway elevation: $210.0 \mathrm{ft}(64.0 \mathrm{~m})$

Damsite 8 - Located just southeast of Damsite 7. Proposed emergency spillway elevation: $240.0 \mathrm{ft}$ (73.6 m)

Levee - Centerline is located along Arroyo los 0lmos just east of Rio Grande City.

Arroyo Roma R.C.\& D. - Located immediately northwest of the village of Roma. Proposed emergency spillway elevation: $242.3 \mathrm{ft}$ $(73.9 \mathrm{~m})$

Elevation: Approximate average elevation above mean sea level as determined by location on U.S.G.S. topographic map.

Description: Specific statements concerning the occupational material at the site, its extent, condition, etc.

Type of Site: Although all the sites here described fall within the area described as the Lomeria. (Nunley 1971), it has been possible to distinguish two different types of locations: Gallery sites are located on terraces or otherwise very close to arroyos and tributaries. Bower sites, on the other hand, are located in the hilly areas 
overlooking the lower-lying arroyos, tributaries and Gallery-type sites.

Soil: Information here derived from the Soil Survey of Starr County, Texas.

Environmenta1 Characteristics: Information concerning the Range Site and vegetation observed in the field is presented here.

Interpretation: A very brief test guess supported by field observations.

Reported by: Individual or institution of record

Remarks: General statements about the site including estimation of its importance and recommendation for future work.

Partial sentences are frequently used to keep verbiage to a minimum in the following descriptions.

41 SR 56

Location: Level terrace surface west of Arroyo Los 01mos at a point about $100 \mathrm{~m}$ north of centerline of damsite $1 \mathrm{~B}$.

Damsite: 1B

Elevation: $260+\mathrm{ft}(79.3 \mathrm{~m})$

Description: Artifactual material eroding from upper, dark brown, sandy midden soil of up to eight centimeters in thickness. Material scattered over about five or six acres (2.0 or $2.4 \mathrm{ha})$. 
Surface Indications: Snail shell concentrations, bifaces, chips, other lithic materials eroding from midden soil.

Type of Site: Gallery, open camp

Sol1: Montell Clay, saline

Environmental Characteristics: Saline Clay Range Site; mesquite, opuntia,brush.

Interpretation: Site likely represents temporary, seasonal occupation.

Reported by: Frank Weir and revisited by UTSA crew

Remarks: This is quite typical of a large Gallery-type of site. Although sheet erosion has badly damaged the stratigraphic evidence, the presence of some buried materials promises data related to relative dating. It is recommended that controlled surface collections and limited excavations be conducted at this site.

41 SR 65

Location: Approximately $200 \mathrm{~m}$ north of U.S. 83 on western terrace of Arroyo 1os 01mos.

Damsite: $1 B$

Elevation: $160 \mathrm{ft}(48.8 \mathrm{~m})$

Description: Lithic cultural materials are eroding from the upper $6-8 \mathrm{~cm}$ of a badly eroded sandy loam. Exact size of the occupational debris was difficult to determine, but seemed to be about $25 \mathrm{~m}$ long and $10 \mathrm{~m}$ wide with the long axis paralleling the arroyo. 
Type of Site: Gallery, open camp

So11: Camargo Silty Clay Loam

Environmental Characteristics: Loamy Bottomland Range

Site; snail concentrations, mesquite, cactus, scattered clumps of grass.

Interpretation: Site was apparently occupled by groups on a temporary seasonal basis.

Reported by: UTSA Center for Archaeological Research

Remarks: This site is especially Interesting, since it represents the southernmost location observed in the present survey. Although badly eroded, the site should be further investigated. TestIng and controlled surface collection is recommended.

\section{SR 66}

Location: Along and both sides of centerline of Damsite 1B east of Arroyo los Olmos, this site forms part of a high, sandy ridge sloping away from the arroyo.

Damsite: 1B

Elevation: $280 \mathrm{ft}(85.3 \mathrm{~m})$

Description: Widely and lightly scattered lithic debris, debitage and tools appear over several hectares of this badly eroded site.

Type of Site: Bower, open camp

So11: Ramadero Loam-Copita Fine Sandy Loam 
Environmenta1 Characteristics: Ramadero Loam Range Site Gray Sandy Loam Range S1te: opuntia, mesquite, scattered grass clumps; bare eroded spaces.

Interpretation: Likely represents a temporary hunting or gathering station.

Reported by: UTSA Center for Archaeological Research

Remarks: Site is so badly damaged by sheet and gully erosion no further work is recommended.

\section{SR 67}

Location: West side of a high ridge overlooking the east bank of Arroyo los 0lmos. The dam centerline bisects this site at a point just across the ridgetop from SR 66 .

Damsite: $1 \mathrm{~B}$

Elevation: $270 \mathrm{ft}(82.3 \mathrm{~m})$

Description: Most of this site has been rootplowed very recently and has thereby been severely damaged. Even so, there remain marginal areas of this large site (approximately $400 \mathrm{~m}$ long) which are relatively undisturbed. The cultural occupation seems to be confined to the upper $10 \mathrm{~cm}$ of a light brown, sandy soil.

Type of Site: Bower, 1arge open camp

Soll: Montell Clay, saline - Copita Fine Sandy Loam

Environmental Characteristics: Saline Clay - Gray Sandy Loam Range Site; cenizo, mesquite, guajillo.

Interpretation: This site likely served as a base camp. 
Reported by: UTSA Center for Archaeological Research

Remarks: This site should be more thoroughly investigated because of its size and the diversity of 11thic materials found. These factors, plus the presence of definite stratigraphy in portions of the site make further exploration mandatory. Intensive controlled surface investigation with excavation of appropriate areas is strongly recommended.

41 SR 68

Location: This site is located northwest of SR 67. It is part of a rootplowed and badly eroded, gravelly sand ridge overlooking Arroyo los 0lmos.

Damsite: 1B

Elevation: $265 \mathrm{ft}(80.8 \mathrm{~m})$

Description: Relatively large numbers of split cobbles, primary flakes, and other debris lie scattered in an oval shape with the long axis extending about $25 \mathrm{~m}$ along the arroyo.

Type of Site: Bower, open quarry

Soil: Copita Fine Sandy Loam

Environmental Characteristics: Gravel outcrops within the Copita Sand here exploited for lithic raw material. Gray Sandy Loam Range Site; mesquite, opuntia.

Interpretation: Quarry/temporary camp

Reported by: UTSA Center for Archaeological Research

Remarks: Site is small and badly damaged with no known stratigraphic depth. No further work is recommended. 
41 SR 69

Location: This site forms the northern end of the same sandy ridge on the eastern side of Arroyo los 0lmos that contains site SR 67 and may represent a continuation of the latter.

Damsite: $1 \mathrm{~B}$

Elevation: $280 \mathrm{ft}(85.3 \mathrm{~m})$

Description: Lithic debris, debitage and tools and burned rocks are scattered over an area of about $70 \times 40 \mathrm{~m}$. Very severe sheet and gully erosion have badly damaged much of the site. In addition, the site has been rootplowed.

Type of Site: Bower, large camp

Soi1: Catarina-Copita Fine Sandy Loam

Environmenta1 Characteristics: Saline Clay-Gray Sandy Loam Range Site; ebony, opuntia, yucca, catclaw, grass clumps.

Interpretation: Temporary campsite

Reported by: UTSA Center for Archaeologica1 Research

Remarks: Site should be investigated further in conjunction with additional work at SR 67. Additional surface survey and testing recommended.

\section{SR 70}

Location: East of Arroyo los 0lmos on bank of small tributary arroyo at the interface between the sandy uplands and the rather silty terraces, this site lies approximately $30 \mathrm{~m}$ north-northwest 
of site SR 69.

Damsite: $1 \mathrm{~B}$

Elevation: $270 \mathrm{ft}(82.3 \mathrm{~m})$

Description: Although rootplowed, areas of this site show

little apparent disturbance. Such undisturbed areas show cultural

material eroding from a dark midden zone of up to $4 \mathrm{~cm}$ in depth.

Great concentrations of snail shells.*

Type of Site: Gallery, open camp

So11: Ramadero Loam

Envirommental Characteristics: Ramadero Range Site; catclaw, opuntia.

Interpretation: Temporary camp

Reported by: UTSA Center for Archaeological Research

Remarks: It was difficult to distinguish the rootplowed areas from the undisturbed areas because of the fact that this site was a turning point for the machinery. At places the plows must have been out of the ground, whereas at other places, the plows

*On, or in the vicinity of, several archaeological sites, the survey team noted the presence of "snail cracking stones", used by paisanos (roadrunners; Geococcyx sp.). The paisano will select a suitable cobble to which it carries land snails, and hits the shells against the rock in order to break them open. As a result of the bird's activity, numerous broken snail shells will accumulate around the "cracking stone". At some Starr County sites, these concentrations were a foot or more in diameter. The difference between those snail shells introduced into a site deposit by man and those brought to the area by the paisano is that the latter are very highly fragmented during the "cracking" process, while the former are usually found whole. An example of a "snail cracking stone" is illustrated by J. B. Holdsworth, Nature Through a Knothole, p. 202 (Naylor, 1969). 
seem to have redeposited whole sections of the site almost intact. Testing of this site is recommended.

41 SR 71

Location: This site is actually a rather poorly defined locale which parallels a shallow swale on the east side of Arroyo los olmos about $300 \mathrm{~m}$ north of SR 70.

Damsite: $1 \mathrm{~B}$

Elevation: $265 \mathrm{ft}(80.8 \mathrm{~m})$

Description: Sheet erosion has badly deflated this site.

Cultural material in the form of snail and burnt rock concentrations and chipped stone artifacts appear in a characteristically wide scatter over a sandy clay surface where they have been deposited by deflation from previously higher deposits.

Type of Site: Gallery, open camp

Soil: Montell clay, saline

Enviromental Characteristics: Saline Clay Range Site: mesquite, cactus, yucca, retama.

Interpretation: Open, probably seasonally occupied campsite

Reported by: UTSA Center for Archaeological Research

Remarks: Materials are so widely scattered and erosional damage is so great that no further work is recommended. 
41 SR 72

Location: This site lies along and both sides of a point about $300 \mathrm{~m}$ east of the western end of the centerline of Damsite $1 B$.

Damsite: $1 B$

Elevation: $285 \mathrm{ft}(86.9 \mathrm{~m})$

Description: Cores, flakes, and processual mid-stages are found interspersed within a gravel outcrop over an area of several hundred square meters.

Type of Site: Bower, open quarry

Soil: Catarina soil

Environmental Characteristics: Saline Clay Range Site:

buffalo grass, curly mesquite, opuntia, tasajillo.

Interpretation: Quarry/temporary camp

Reported by: UTSA Center for Archaeological Research

Remarks: Site has been considerably damaged by gully erosion, but is typical of small quarry/workshop sites located in the course of this investigation. It might be considered for further work in conjunction with a study of quarries in the area. Further consideration is therefore recommended.

$41 \operatorname{SR} 73$

Location: This site is bisected by a dirt road about $100 \mathrm{~m}$ north of Damsite IB and intergrades with the northeastern extremes 
of site SR 72.

Damsite: $1 \mathrm{~B}$

Elevation: $275 \mathrm{ft}(83.8 \mathrm{~m})$

Description: Site occupation in the shape of an oval with long axis running $\mathrm{NW} / \mathrm{SE}$ about $120 \mathrm{~m}$. Gully and sheet erosion have damaged the site considerably. Former surface remnants, platformed by plant roots, display occupational material to a depth of $2-3 \mathrm{~cm}$ below surface.

Type of Site: Bower, open camp

Soil: Copita Fine Sandy Loam

Environmental Characteristics: Gray Sandy Loam Range Site: cenizo, yucca, mesquite, ebony, opuntia, guajillo.

Interpretation: Occupation at site was probably seasonal and temporary, and Involved relatively large groups. Site SR 72 may be an assciated quarry.

Reported by: UTSA Center for Archaeological Research

Remarks: Although this site has been rather heavily damaged by erosion, the possibility of obtaining some stratified data makes further work here potentially important. Testing and further survey are recommended.

\section{SR 74}

Location: Bones protrude from the eastern wall of Arroyo Ios 01mos at a point about $4 \mathrm{~km}$ upstream from Damsite $1 \mathrm{~B}$.

Damsite: 1B

Elevation: Wall of Arroyo los 0lmos - $260 \mathrm{ft}(79.3 \mathrm{~m})$ 
Description: Bones later identified as modern horse remains, were found in situ eroding from the lower terrace of Arroyo los Olmos. It was not determined whether the deposit containing the bones is of sufficient age to be of historical interest.

Type of Site: Buried

So11: Buried terrace

Environmental Characteristics: Not applicable

Interpretation: The geology of the site is not understood. The presence of a few flakes, chunks, and other artifacts within the same deposit as the bones, further complicates the situation.

Reported by: UTSA Center for Archaeological Research

Remarks: This site is typical of many in the arroyo bottoms. Bones of various kinds, usually horse, are commonly found at similar sites in possible association with lithic artifacts. Further work should be done at these sites to determine the exact nature of this apparent relationship. Exploratory excavations and sectioning are recommended.

41 SR 75

Location: This site occupies most of the NE portion of a high hill overlooking Arroyo los 0lmos from the west. The hill lies approximately $2.5 \mathrm{~km}$ north of the centerline of damsite $1 \mathrm{~B}$.

Damsite: $1 B$

Elevation: $290 \mathrm{ft}(88.4 \mathrm{~m})$ 
Description: Occupational debris is eroding from an area of $200-250$ square meters on the northeast portion of the hill. Material is exposed primarily in most severely exoded areas where grass cover is absent. Burnt rock, snail she1ls, and chipped lithic material are characteristic.

Type of Site: Bower, open camp

Soil: Zapata soils

Environmental Characteristics: Shallow Ridge Range Site: guajillo, cenizo, ebony, wild persimmon, mesquite, yucca, opuntia. Interpretation: This site seems to have been occupied by fairly large groups for relatively long periods, perhaps on a seasonal basis.

Reported by: UTSA Center for Archaeological Research

Remarks: Because of the rather unique and somewhat interesting location of this site in relation to the surrounding environment, and also because of the promise of some stratigraphic data, further work at this site is important. Additional survey and initial testing is recommended.

\section{SR 93}

Location: This quite extensive site is located about $6 \mathrm{~km}$ due north of the western end of Damsite $1 \mathrm{~B}$ and extends along a terrace. of Arroyo los 01mos for about $600 \mathrm{~m}$.

Damsite: $1 \mathrm{~B}$

Elevation: $270 \mathrm{ft}(82.3 \mathrm{~m})$ 
Description: Lithic scatter covers an area of approximately $600 \times 50 \mathrm{~m}$ parallel to the Arroyo. Sma11, dry, saline ponds characterize this site.

Type of Site: Gallery, open camp

Soil: Brennan Pine Sandy Loam

Environmental Characteristics: Sandy Loam Range Site: mesquite, cactus, wild persimmon, brush.

Interpretation: Site repeatedly occupied by relatively large groups, probably for extended periods of time. Activities could have conceivably included salt extraction.

Reported by: UTSA Center for Archaeological Research

Remarks: Since this site is one of the most extensive discovered in the course of the present survey, and since it has artifacts that are distinctively different from others found in this survey, further work is needed here. Controlled surface collections and initial testing are recommended.

\section{SR 94}

Location: Site situated atop high ridge overlooking terraces of Arroyo los 01mos from a point about $.5 \mathrm{~km}$ east of the arroyo and $.5 \mathrm{~km}$ south of $\mathrm{SR} 93$.

Damsite: $1 \mathrm{~B}$

Elevation: $298 \mathrm{ft}(90.8 \mathrm{~m})$

Description: Severe sheet erosion has stripped away original 
upper occupational debris bearing deposits and lowered the artifacts onto a rather hard, erosion-resistant sandy clay floor. Artifacts are scattered over a surface area of approximately $300 \times 100 \mathrm{~m}$

Type of Site: Bower, open camp

Soil: Copita Fine Sandy Loam

Environmental Characteristics: Gray Sandy Loam Range Site: chapote, yucca, mesquite, ebony, cenizo.

Interpretation: This site is typical of the temporarily occupied, seasonal campsites in this area.

Reported by: UTSA Center for Archaeological Research

Remarks: The site is interesting because it is so typical of the severely eroded, ambiguously defined, open sites characteristic of the area. No further work is recommended.

41 SR 95 (Fig. 2)

Location: East bank of Arroyo los 01mos, about $200 \mathrm{~m}$ from present channel on a swale between two stock tanks. Locale lies about halfway between $\underline{S R ~} 71$ and SR 96 .

Damsite: IB

Elevation: $268 \mathrm{ft}(81.7 \mathrm{~m})$

Description: Occupational material is exposed by sheet erosion in upper several centimeters of light brown sandy soll and is deposited on hard sandy clay floor. This site is archetypical for the area except that it seems to have fairly large areas still relatively undisturbed. 
Type of Site: Gallery, open camp

Soil: Montell clay, saline

Environmental Characteristics: Saline Clay Range Site: saladillo, mesquite, tasajillo.

Interpretation: This site may represent repeated seasonal occupation by relatively small groups.

Reported by: UTSA Center for Archaeological Research

Remarks: This is one of the most typical sites of those in the area. In addition, relatively large portions are und isturbed. Therefore, it is recommended that extensive excavations be undertaken at this site.

41 SR 96

Location: Artifacts are exposed here in the bed of Arroyo los 0lmos, approximately .5 km SE of SR 93.

Damsite: $1 B$

Elevation: Bed of Arroyo 1os 0lmos, $270 \mathrm{ft}(82.30 \mathrm{~m})$

Description: Artifacts exposed in area of disconformity between dark gray member containing modern horse and bison and a mottled gray, reworked member, containing mammoth remains.

Type of Site: Buried terrace

Soil: Not applicable

Environmental Characteristics: Not applicable

Interpretation: This site is another example of the anomaly prevailing between bone-bearing deposits in the arroyo bed, and the clustering of artifacts in those same deposits. The association 
between these bones and the artifacts is not at all clear.

Reported by: UTSA Center for Archaeological Research

Remarks: This site should be included in an extensive survey of sites in the walls and bed of the Arroyo los 01mos. It is therefore recommended that this site be further explored by means of test excavations.

\section{SR 97}

Location: This site includes an area of approximately 1.21 ha stretched along the crest and slopes of a ridge paralleling a tributary arroyo of the Arroyo los Olmos about $1 \mathrm{~km}$ ENE of the southern end of the centerline of Damsite 7 .

Damsite: 7

Elevation: $200 \mathrm{ft}(61.0 \mathrm{~m})$

Description: Lithic artifacts are mingled with gravels throughout an area of about $600 \times 200 \mathrm{~m}$. Split cobbles and primary flakes are the dominant artifacts.

Type of Site: Bower, open quarry

Soil: Copita Fine Sandy Loam

Environmental Characteristics: Gray Sandy Loam Range Site with heavy gravel outcrop (Reynosa Formation): mesquite, cactus, and grass clumps.

Interpretation: Judging from the kind of lithic material, it is clear this was a quarry area, probably temporarily occupied. Reported by: UTSA Center for Archaeological Research 
Remarks: The site would be interesting as part of a comprehensive study of prehistoric stone quarries in the area. Otherwise, no further work is recommended.

41 SR 98

Location: This site is part of the northern bank of a small tributary about $1.5 \mathrm{~km}$ NE of the centerline of Damsite 7 .

Damsite: 7

Elevation: $200 \mathrm{ft}(61.0 \mathrm{~m})$

Description: Lithic materials exposed in an area of $100 \times 20$

m with the long axis parallel to small tributary.

Type of Site: Gallery, open camp

Soil: Loam bordered by Copita Fine Sandy Loam

Environmental Characteristics: Ramadero Range Site; Gray

Sandy Loam Range Site; Reynosa Gravels; mesquite and cactus.

Interpretation: This represents another quarry/temporary occupation site.

Reported by: UTSA Center for Archaeological Research

Remarks: This site might be included in a study of prehistoric quarries in the area. If it is not, no further work is recommended here.

41 SR 99

Location: This site is located in the northeastern portion of the proposed reservoir for Damsite 7 . It is situated mainly along a 
badly eroded side arroyo which empties into the major arroyo of Damsite 7 .

Damsite: 7

Elevation: $210 \mathrm{ft}(64.0 \mathrm{~m})$

Description: Site extends one $\mathrm{km}$ along a badly eroded arroyo. Great quantities of chipped stone material are found throughout the area. Desert pavement covers much of the immediate area.

Type of Site: Gallery, open camp

Soil: Copita Fine Sandy Loam/Ramadero Loam

Environmental Characteristics: Gray Sandy Loam Range SiteRamadero Range Site: Reynosa gravels; mesquite, cactus.

Interpretation: This site evidently represents repeated occupations, probably by relatively small groups.

Reported by: UTSA Center for Archaeological Research

Remarks: The heavy concentration of lithic debris and debitage at this site is a little surprising in view of the relative paucity of finished tools. Although the site is badly damaged by erosion, further work is needed here. An intensive controlled surface collection is recommended for this site.

41 SR 100

Location: Near the north end of centerline of Damsite 7 where two roads cross, great quantities of lithic artifacts are exposed in roads and eroded areas.

Damsite: 7

Elevation: $200 \mathrm{ft}(61.0 \mathrm{~m})$ 
Description: Lithic materials are exposed over an area of about .81 ha. Platformed remnants of a stratigraphically higher soil indicate a depth of $2-3 \mathrm{~cm}$ of culture-bearing light brown sand.

Type of Site: Gallery, open camp

So11: Copita Fine Sandy Loam

Environmental Characteristics: Gray Sandy Loam Range Site: mesquite, cactus, retama and willow

Interpretation: This is apparently a site occupied by small, seasonally nomadic groups.

Reported by: UTSA Center for Archaeological Research

Remarks: Several areas of this site offer the promise of stratigraphic data. Testing and intensive surface collections are recommended here.

41 SR 101

Location: Located just west of the central portion of Damsite 7, this site consists of widely scattered, chipped stone artifacts mingled in a deposit of Reynosa Gravels and overlooking a small tributary creek.

Damsite: 7

Elevation: $210 \mathrm{ft}(64.0 \mathrm{~m})$

Description: Occupational materials extend for a distance of about $40 \mathrm{~m}$ along the tributary creek. Otherwlse, both size and shape of this site are undetermined.

Type of Site: Bower, open quarry

Soil: Reynosa Gravel 
Environmental Characteristics: Gray Sandy Loam Range Site. Interpretation: This was obviously a quarry site.

Reported by: UTSA Center for Archaeological Research Remarks: The site requires no further work.

41 SR 102

Location: This site is located approximately $170 \mathrm{~m}$ upstream from site SR 100.

Damsite: 7

Elevation: $190 \mathrm{ft}(57.9 \mathrm{~m})$

Description: The site is partly buried under a light tan, sandy soil. Size of the site was not determined, but there is a relatively large amount of chipped stone material.

Type of Site: Bower, open camp

So11: Copita Fine Sandy Loam

Environmental Characteristics: Gray Sandy Loam Range Site: thorny bushes, cenizo, mesquite, cactus, Spanish dagger.

Interpretation: Site represents repeated numerous occupations by relatively small groups.

Reported by: UTSA Center for Archaeological Research

Remarks: The location of this site, the possibility of collecting data from undisturbed strata, and the relative abundance of lithic material make the further investigation of this site obligatory. Preliminary excavations are recommended. 
41 SR 103

Location: This site is located about $200 \mathrm{~m}$ upstream from SR 102.

Damsite: 7

Elevation: $190 \mathrm{ft}(57.9 \mathrm{~m})$

Description: Lithic artifacts are eroding from a light tan sandy soil. Most of the occupational material appears in gullies and other severely eroded areas where it is washing from the upper 2-3 $\mathrm{cm}$ of the upper sandy soil.

Type of Site: Bower, open camp

Soil: Copita Fine Sandy Loam

Environmental Characteristics: Gray Sandy Loam Range Site: thorny bushes, cenizo, cactus, Spanish dagger, mesquite.

Interpretation: This site is a typical example of a temporarily occupied, seasonal campsite.

Reported by: UTSA Center for Archaeological Research

Remarks: Since the site shows some promise of yielding stratigraphic data, and since it is located in the area of Damsite 7, testing is recommended.

41 SR 104

Location: This site lies $150 \mathrm{~m}$ upstream from $\underline{\mathrm{SR} 103}$ and is in essentially the same environmental position.

Damsite: 7 
Elevation: $190 \mathrm{ft}(57.9 \mathrm{~m})$

Description: Occupational materials are buried beneath one to two $\mathrm{cm}$ of a light tan sandy soil. These matertals are exposed by gully erosion over an area of about $200 \mathrm{~m}$ in diameter.

Type of Site: Bower, open camp

Soil: Copita Fine Sandy Loam

Environmental Characteristics: Gray Sandy Loam Range Site: grasses, mesquite, thorny bushes, cenlzo, cactus.

Interpretation: This is another temporarily occupied, seasonal campsite.

Reported by: UTSA Center for Archaeologica1 Research

Remarks: This site is similar to several others in this reservoir, and should be tested with them in a program of sampling to determine the relationship of these sites to one another and the ecology of the area.

41 SR 105

Location: Located about $0.7 \mathrm{~km} \mathrm{SSE}$ of the $2+30$ turning point of Damsite 7, this site is distinguished by twin arches formed by looping a portion of used automobile tires between the upright ends of cedar posts.

Damsite: Near Damsite 7

Elevation: $200 \mathrm{ft}(61.0 \mathrm{~m})$

Description: This site lies on edge of uplands overlooking the tributary to be dammed at Damsite 7. Prehistoric 1ithic material is thinly scattered over the surface of about one acre. Surface is 

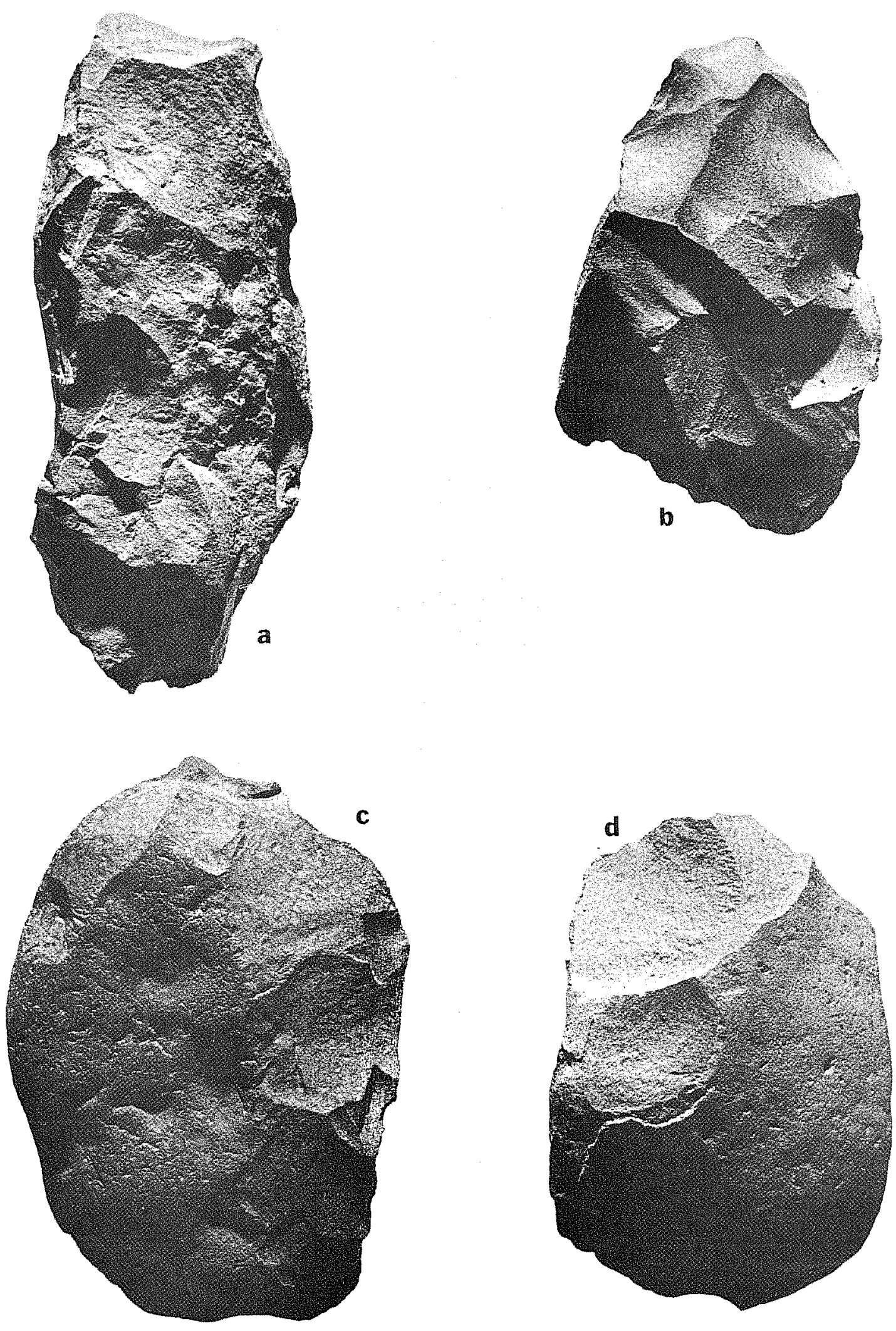
cross section with retouch along the thin edge, thus forming a cutting or scraping tool.

25. Uniface, Flake, With Cortex, Prepared Platform, Secondary Flakes, Heavy Retouch, (Fig.13,d,e),

Varia. All of these specimens have traditionally been classified as scrapers of various kinds, and most probably were used in scraping or cutting tasks.

26. Uniface, Flake, With Cortex, Secondary Flake, Cortex on Dorsal Surface, Varia. These specimens display varying degrees of retouch. Bulbs of percussion have been totally or partially removed from many.

27. Uniface, Flake, With Cortex, Secondary Flake, Prepared Platform, Light Retouch,

Varia. Four of these pieces are made on blades. The remainder are ordinary flakes with varying degrees of light retouch.

28. Uniface, Flake, With Cortex, Cortex Platform,

Side Edge Retouch. Eight of these specimens are made on blades.

29. Uniface, Flake, With Cortex, Cortex Platform, Edge Opposite Bulb Retouched.

30. Uniface, Flake, With Cortex, Cortex Platform, (Fig. 13,2,b,c), Discoidals. Some of these specimens may have functioned as scrapers.

31. Uniface, Flake, With Cortex, Cortex Platform, Denticulates and Notches. These are similar to the artifacts described in Class 36. 

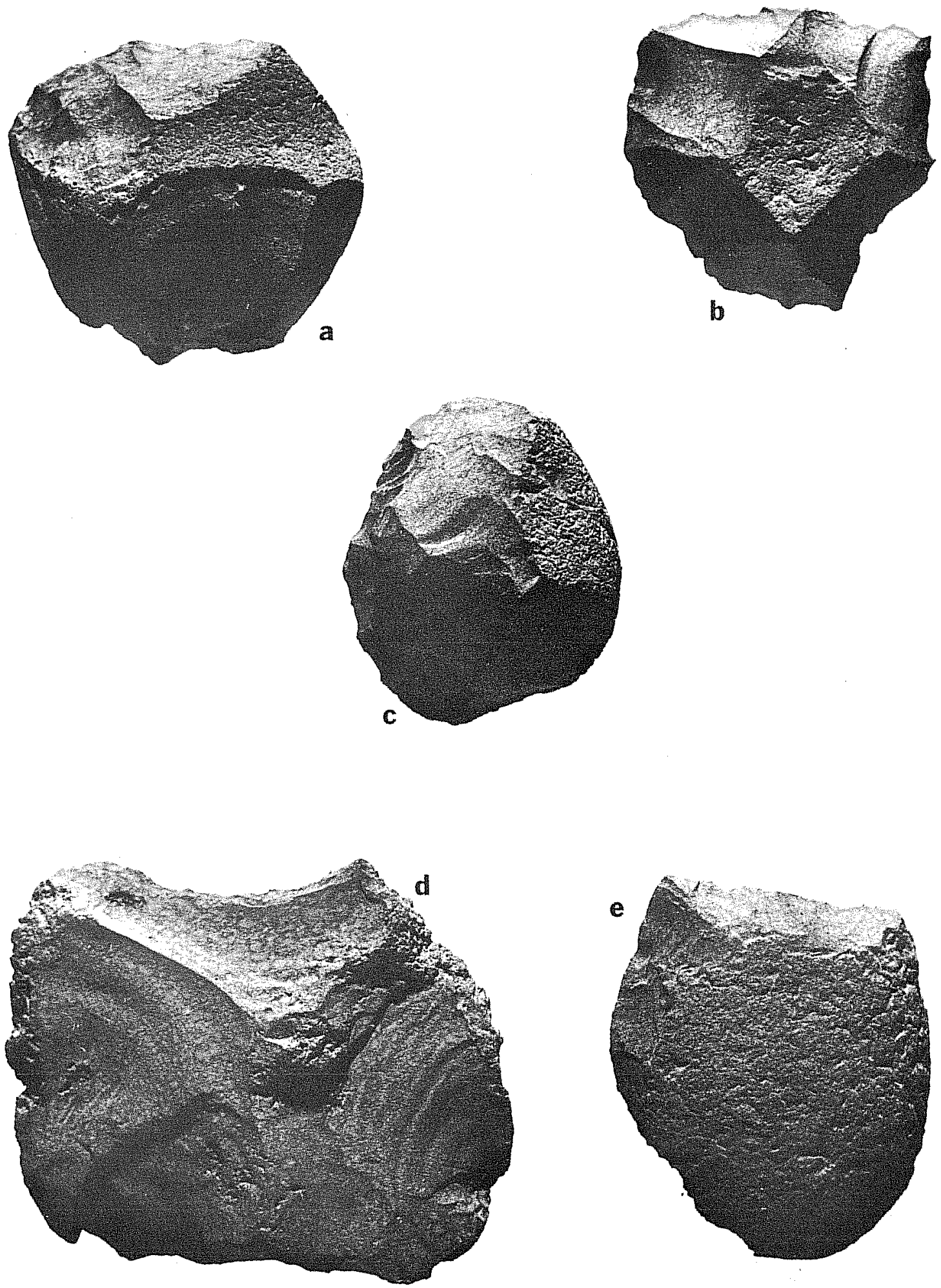

Figure 13. Unifaces. $a, b, \& c$, class $30 ; d \& e$, class 25. (Artifacts are illustrated actual size). 
32. Uniface, Flake, With Cortex, Cortex Platform, (Fig.14,c,f,g), Small Varia. Scraping and cutting edges are found on these specimens.

33. Uniface, Flake, Without Cortex, Shaped Varia. These specimens have been deliberately shaped by various retouch styles. Shapes include Ovate, Discoidal, Subrectangular, etc. No particular shape is prevalent. Most of these pieces would be classed as miscellaneous scrapers and scraper fragments. Three are similar to certain "gouges" from the Falcon area.

34. Uniface, Flake, Without Cortex, Unshaped, (Fig. 14,a), Varia 1 . These pieces are very lightly retouched but in no apparent pattern.

35. Uniface, Flake, Without Cortex, Unshaped, Varia II. These specimens all bear edge retouch so slight that it may be the result of either use or accident.

36. Uniface, Flake, Without Cortex, (Fig. 14,c,d), Notches and Denticulates. A11 these pieces are completed tools. Thirteen have notches chipped into one edge, while the remainder have denticulated edges.

37. Uniface, Flake, Without Cortex, (Fig. 14,b), End or Edge Retouch. Six of these are small and scrapers made on "arched" (Concavo-convex) flakes. The remainder are lateral side scrapers made on blades and flakes. 
Figure 14. Unifaces

a, Class $34 ; \mathrm{b}$, Class $37 ; \mathrm{c}$, Class 36 , notches; d, Class 36 , denticulates; e,f, and g, Class 32. (Artifacts are illustrated actual size). 


$$
\begin{aligned}
& 600 \\
& -80
\end{aligned}
$$

01 
PROVENIENCE TABLE I

BIFACES, UNDER $1.0 \mathrm{CM}$. THICK

\begin{tabular}{|c|c|c|c|c|c|c|c|c|c|}
\hline \multirow{2}{*}{$\begin{array}{l}\text { Site } \\
\text { Number }\end{array}$} & \multicolumn{9}{|c|}{ Class } \\
\hline & 1 & 2 & 3 & 4 & 5 & 6 & 7 & 8 & Tota 1 \\
\hline $41 \mathrm{SR} 65$ & & & & & & & & 1 & 1 \\
\hline 66 & & & & 1 & & & & 1 & 2 \\
\hline 67 & & 1 & & 1 & 1 & 1 & & 6 & 10 \\
\hline 69 & 1 & & 1 & & & & & 1 & 3 \\
\hline 71 & 5 & 1 & & & & & & 5 & 11 \\
\hline 73 & 1 & & 1 & & & 1 & & 2 & 5 \\
\hline 75 & & 2 & 3 & & 1 & & 2 & 5 & 13 \\
\hline 93 & 1 & 2 & 1 & & & 1 & 3 & 4 & 12 \\
\hline 97 & & & & & & & & 1 & 1 \\
\hline 98 & & & & & 1 & 1 & & 1 & 3 \\
\hline 99 & & & & 1 & & & & 3 & 4 \\
\hline 100 & & & 1 & & & 1 & & 2 & 4 \\
\hline 102 & & & & & & 1 & & 1 & 2 \\
\hline 105 & 1 & 1 & & & & & & & 2 \\
\hline 106 & & & & & & & & 2 & 2 \\
\hline 108 & & 1 & 1 & & 1 & & 1 & 4 & 8 \\
\hline 109 & & & & & & 1 & & & 1 \\
\hline 110 & & & & & & & & 1 & 1 \\
\hline 111 & & & & & & & & 1 & 1 \\
\hline 113 & & & · & 1 & & & & 2 & 3 \\
\hline 115 & & & & & & & & 1 & 1 \\
\hline 116 & & & & & & & & 2 & 2 \\
\hline 118 & & & & & 1 & & & 1 & 2 \\
\hline 119 & & & & & & 1 & & 2 & 3 \\
\hline 120 & 1 & & & & & & & & 1 \\
\hline 123 & 1 & 2 & & 1 & & & & & 4 \\
\hline 125 & 1 & & & & & & & & 1 \\
\hline 126 & 1 & & & 1 & & & & & 2 \\
\hline 127 & & & & & & & & 2 & 2 \\
\hline 128 & & 1 & & & & & & & 1 \\
\hline 131 & & & & 1 & & & & 2 & 3 \\
\hline 132 & - & - & - & - & $\underline{1}$ & - & - & - & 1 \\
\hline Total & 13 & 11 & 8 & 7 & 6 & 8 & 6 & 53 & 112 \\
\hline
\end{tabular}


PROVENIENCE TABLE II

BIFA CES, OVER 1.0 CM. THICK

\begin{tabular}{|c|c|c|c|c|c|c|c|c|c|c|c|c|c|c|}
\hline \multirow{2}{*}{$\begin{array}{c}\text { Site } \\
\text { Number }\end{array}$} & \multicolumn{14}{|c|}{ Class } \\
\hline & 9 & 10 & 11 & 12 & 13 & 14 & 15 & 16 & 17 & 18 & 19 & 20 & 21 & Total \\
\hline $41 \mathrm{SR} 66$ & & 1 & & 1 & & & & & & 1 & & & & 3 \\
\hline 67 & & 2 & 2 & 4 & 2 & 2 & 4 & 4 & 1 & 2 & 1 & & 1 & 25 \\
\hline 69 & 1 & & 1 & 1 & 2 & 1 & & & & 1 & & & 1 & 8 \\
\hline 70 & & & 1 & & & 1 & 1 & & 1 & 1 & & & & 5 \\
\hline 71 & 3 & 1 & 1 & & & & & 1 & & & & 1 & & 7 \\
\hline 72 & 1 & & 1 & & & & & & 1 & 1 & & & 1 & 5 \\
\hline 73 & & 1 & 3 & 4 & & & 1 & & 1 & 2 & & 1 & & 13 \\
\hline 75 & 2 & 1 & 1 & & 5 & & 1 & & 1 & 1 & 1 & & 2 & 15 \\
\hline 93 & & 2 & 2 & 2 & 1 & & 1 & 2 & 3 & 1 & & 1 & 3 & 18 \\
\hline 96 & & & & & & 1 & 1 & & & 1 & & & 1 & 4 \\
\hline 97 & 1 & & 1 & 1 & 2 & & & & 1 & 1 & 1 & & & 8 \\
\hline 98 & & & & & & & & & & & & & 1 & 1 \\
\hline 99 & 1 & & & & & I & & 1 & & & & & 1 & 4 \\
\hline 100 & 1 & 1 & 1 & 2 & 3 & 1 & & & 1 & 2 & & & 1 & 13 \\
\hline 102 & & & 3 & 2 & & & & 2 & & & & & & 7 \\
\hline 103 & & 1 & & 2 & & & & & & & & & & 3 \\
\hline 104 & & & & & & & & & 1 & & & & 1 & 2 \\
\hline 105 & & 1 & & & 1 & & & 1 & & 1 & & & & 4 \\
\hline 106 & & 1 & 1 & & 1 & & & & & & & & & 3 \\
\hline 108 & 3 & 8 & & & 3 & & 1 & 1 & 2 & & 4 & 1 & 1 & 24 \\
\hline 109 & & 1 & & & 1 & & & & & & & & & 2 \\
\hline 110 & & & 1 & & & 1 & & & 1 & & & & & 3 \\
\hline 111 & 1 & 1 & & 1 & 1 & & & 2 & 1 & & & & & 7 \\
\hline 114 & & & & & & 1 & & & & 1 & & & & 2 \\
\hline 115 & & 1 & & 1 & & & & & & & & 1 & & 3 \\
\hline 116 & & 2 & & & & & & & 1 & & & 3 & & 6 \\
\hline 117 & & & 1 & & 1 & & 1 & & & & & & & 3 \\
\hline 118 & & & & & & & 1 & & 1 & & & 2 & 1 & 5 \\
\hline 119 & 1 & 2 & & 1 & 2 & 1 & 2 & & 2 & 3 & 2 & & 5 & 21 \\
\hline 120 & & & & 1 & & & 1 & & & & & & & 2 \\
\hline 121 & & & & & 1 & & & & & & & & & 1 \\
\hline 123 & & & 1 & & 1 & 2 & & 1 & 1 & & & & & 6 \\
\hline 124 & & & 1 & & 1 & & & & & & & & & 2 \\
\hline
\end{tabular}


PROVENIENCE TABLE II (cont'd)

\begin{tabular}{|c|c|c|c|c|c|c|c|c|c|c|c|c|c|c|}
\hline \multirow{2}{*}{$\begin{array}{c}\text { Site } \\
\text { Number }\end{array}$} & \multicolumn{14}{|c|}{ Class } \\
\hline & 9 & 10 & 11 & 12 & 13 & 14 & 15 & 16 & 17 & 18 & 19 & 20 & 21 & Total \\
\hline $41 \mathrm{SR} 125$ & 1 & 2 & 1 & & 1 & 1 & 4 & & & 1 & 1 & 2 & 1 & 15 \\
\hline 126 & 1 & 1 & & 1 & 1 & & 2 & & & & & 2 & & 8 \\
\hline 127 & 1 & 1 & 1 & & & & & & & & & & & 3 \\
\hline 128 & 1 & & & & & & & & & & & & & 1 \\
\hline 129 & & & & & & & 1 & & & & & & & 1 \\
\hline 131 & & 2 & 1 & & & 1 & 1 & & & & & & & 5 \\
\hline 132 & 1 & 1 & 1 & 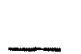 & 1 & - & 1 & 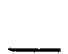 & 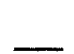 & 1 & 2 & 1 & 1 & 10 \\
\hline Total & 20 & 34 & 26 & 24 & 31 & 14 & 24 & 15 & 20 & 21 & 12 & 15 & 22 & 278 \\
\hline
\end{tabular}


PROVENIENCE TABLE III

\section{UNIFA CES}

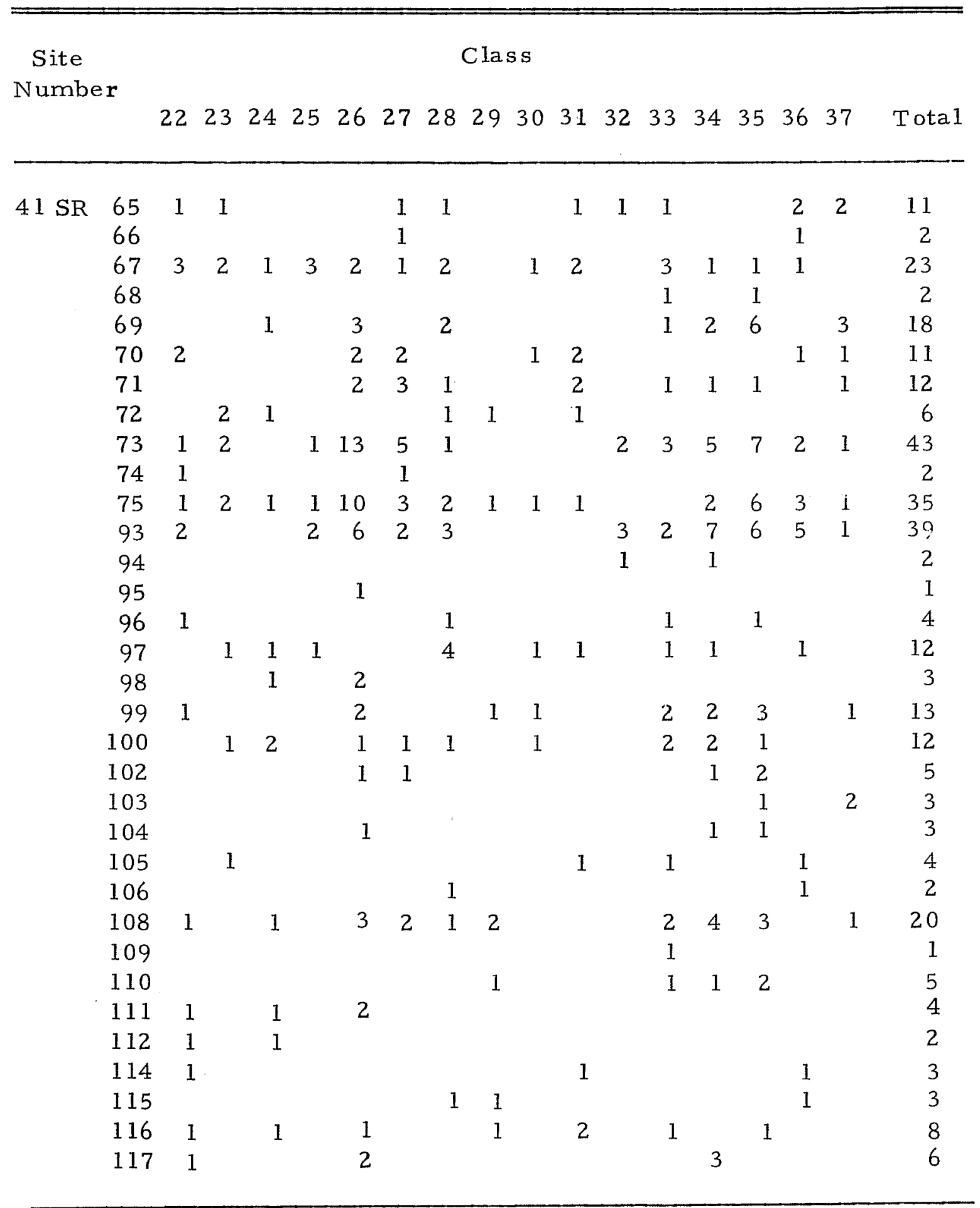


PROVENIENCE TABLE III (cont'd)

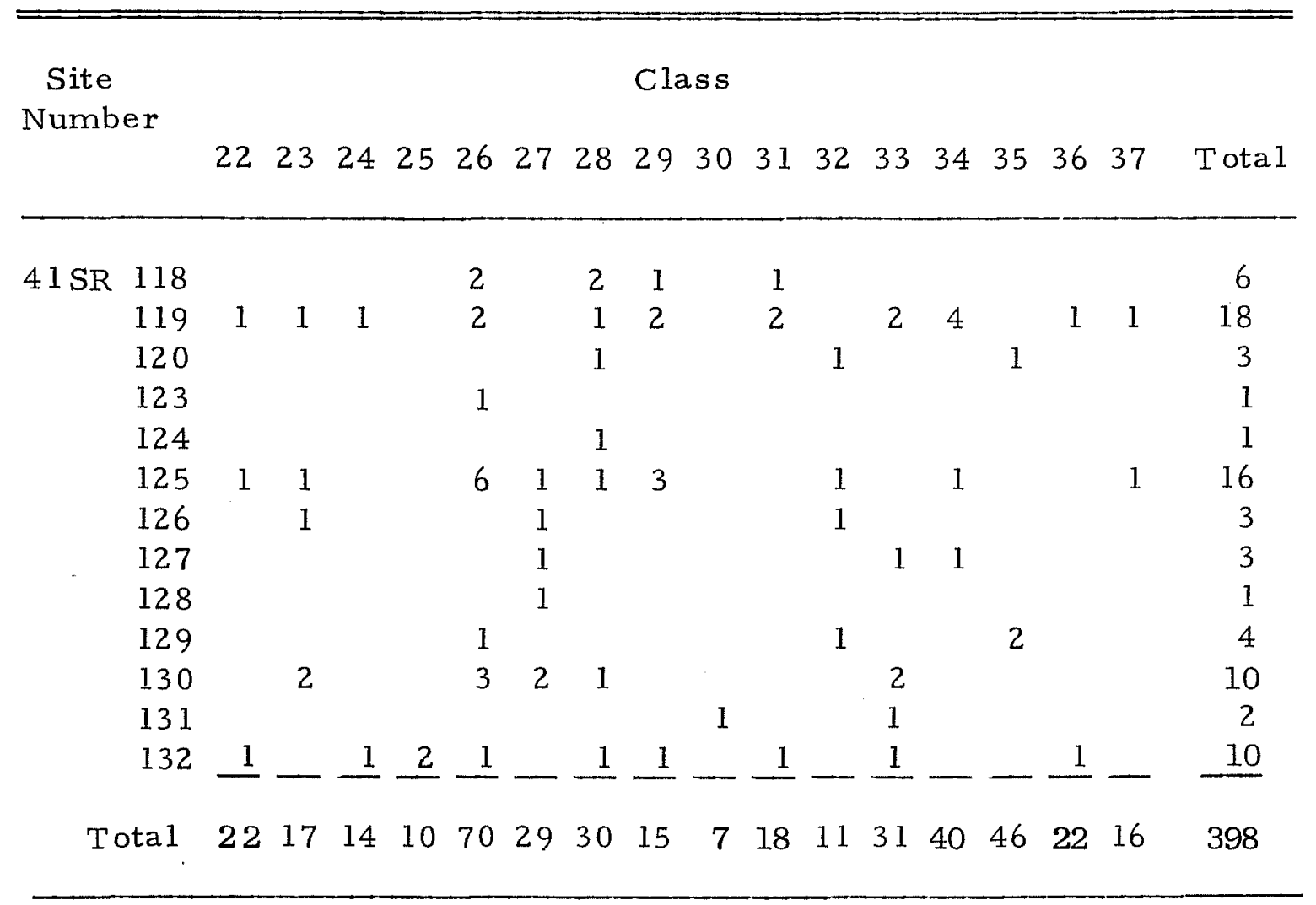


SUMMARY AND RECOMMENDATIONS

\section{Summary}

During August, 1974, personnel of the Center for Archaeological Research at the University of Texas at San Antonio conducted an archaeological survey in the areas to be affected by nine proposed floodwater retarding structures in Starr County, southern Texas. As a result of this survey, a total of 52 archaeological sites was documented.

As we noted earlier, sites are generally found in two distinct topographic locales. Gallery sites, of which 27 were found, are situated on stream terraces or in close proximity to a watercourse. Bower sites are represented by 23 examples, and are located in the hilly uplands overlooking the gallery sites and the stream channels. Two deeply buried sites, not fitting either category, were also documented.

of the total number of recorded sites, 36 apparently represent temporary occupations. The nature of these temporary utilizations of site areas is hard to define. Some of the occupations represent repeated short-term visits to preferred campsites, perhaps on a seasonal basis or during the subsistence round; others may have been single episodes devoted to specific hunting and/or gathering functions. Only three sites appear to have been multi-purpose, major occupation localities (base camps). Ten sites can be described as quarries or lithic workshops, and at most of these, there is some evidence of brief occupation. Additionally, there were two enigmatic sites with bone-bearing deposits, and one other site whose function is 
completely unknown. It is interesting to observe that the temporary and major occupation sites are rather evenly divided between the Gallery and Bower locales. Quarry sites, however, are primarily in the Bower (upland) areas.

At many of the temporary sites, it is likely that few, if any, diagnostic tools were ever discarded or lost. At larger sites, many of these specimens have apparently been collected by relic hunters. Given the absence of any significant number of diagnostic artifacts and the fact that the region lacks a sound chronology, we have no way at present of determining the age of the vast majority of these sites. * Many of them certainly date from the "Archaic"; no recognizable evidence of late prehistoric ("Neo-American") occupation, represented by arrow points or ceramics, was found. A possible Pleistocene occupation is suggested at site 41 SR 120, a Bower site.

In the past few years, studies of settlement distribution have been made in parts of southern Texas (Newton 1968; Nunley 1971a; Hester, 1971; Shafer and Baxter 1975). The major studies have been in widely separated areas, and the picture that is emerging is one of differing settlement patterns from one area to another. The early, and quite generalized, published statements on the prehistory of

\footnotetext{
*Shafer and Baxter (1975) in a recent survey in McMullen and Atascosa Counties, southern Texas, have also remarked on the difficulties of determining the age of their sites since diagnostics had been removed by collectors. The numbers of artifact collectors, and the quantities of artifacts which they have amassed in the southern Texas area, is nothing short of incredible. We feel it is safe to say that in most parts of this region, any attempts to determine site function or temporal placement on the basis of surface collections will be, at the least, terribly biased.
} 
southern Texas have led some archaeologists to think of the regional archaeology as broadly uniform. As the tempo of research increases, it is becoming evident that there is no general settlement distribution scheme which one can apply to the region. Similarly, there are wide areal differences in the lithic tool kits. Rather, it is too be expected that future archaeological studies will reveal many localized settlement patterns and tool kits reflecting aboriginal adaptations to local environments and to the seasonally available water and food resources.

\section{Recommendations}

Presented here is a summary of individual recommendations concerning each site contained within the site description portion of this report. The information is summarized in tabular form in which the following data are presented:

Site Number. The number of the site in Starr County is presented without the state and county appendages.

Degree To Be Affected. The number in this column refers to the location of the site with regard to potential damage caused by the proposed modification. The number " 1 " refers to those sites to be most directly and irrevocably damaged by the proposed work. These sites lie either on or very near the proposed centerline of the various damsites and will be either partially or totally destroyed by construction activities, or they lie in the area of the conservation pool. The number "2" refers to those sites which lie within the 100-year flood pool, while "3" refers to those sites which lie outside the area to be directly affected by any of the proposed modifications. 
Potential Importance. Numbers in this column reflect the degree of scientific, historic, or prehistoric importance of the site in relation to its assessed potential. The most potentially important sites are given a ranking of " 1 " whereas the least important are ranked "4".

Intensity. Numbers in this column were obtained by multiplying the degree a site will be affected by its potential importance. The resulting number is an estimate of the order or priority to be given in any subsequent work. The most urgent work would be indicated by relatively low intensity numbers, whereas relatively high intensity numbers would indicate that no further work should be done at that site. Recommendations. These statements are to be construed as the minimum work recommended at the various sites and not the only work to be done there. Each site will need to be reconsidered as data from it accumulate, and decisions concerning additional work should be made at that time. It will be noted that some recommendations are made for additional work at sites with relatively high intensity numbers. This work should be postponed until work at the sites with low intensity numbers has been completed.

The sites of obvious significance (i.e., those with low intensity numbers) are possible candidates for the National Register of Historic Places. Further work in the project areas may lead to the nomination of these, and possibly other sites to the Register.

of the total number of archaeological sites listed in Table 4, we believe that 18 warrant further work in the form of test excavation and controlled surface collection, activities which can be termed 
"intensive survey". Testing and controlled collection should be undertaken in the coming months, during the period in which the planning for development of the several projects is underway. Intensive survey would permit archaeologists to obtain a more meaningful assessment of these prehistoric resources, and of the impact on them, if any, which might result from reservoir development. The original survey described in the present report had limited objectives and was additionally restricted through time constraints. The survey allowed us to recognize the potential of these 18 sites, but more study is required to properly evaluate them.

In Table 4, five sites are recommended for excavation. Our initial survey has determined that these sites are of particular significance, and that they are probably worthy of nomination to the National Register of Historic Places. However, it may be that some of the 18 sites mentioned above are of similar importance, a fact which could be determined by further field checks. Thus, we are not prepared at this time to offer any firm recommendations (other than a program of test excavation) regarding the five sites proposed for excavation, since further field checks of the sites might lead to modification of such recommendations.

A period of intensive survey should precede any final recommendations regarding adverse impacts of the SCS projects on the archaeological resources of the area. We believe that the results of this intensive survey would also benefit SCS and local planners in their continuing studies on project development. 
Such a program of intensive survey would require approximately one month of field work and another one and one-half months of analysis and evaluation. We have prepared a preliminary budgetary estimate of the costs that might be involved in such a program. We believe the field work and analysis would require expenditures along the following lines: salaries of one field archaeologist, one field assistant, and two laboratory assistants; supplies and expenses; travel and per diem; report preparation; staff benefits (at $.064 \%$ of salaries) and University indirect costs (at $27 \%$ of salaries). The total estimated cost would be $\$ 6,000$.

We do not believe we are presently in a position to provide any viable cost estimates for a full program of mitigation. Certainly, the five sites recommended for excavation in Table 4 might be included in such mitigation activities; it is possible that the findings of the intensive survey would add others to this list. 


\section{TABLE IV}

SUMMARY OF THE IMPACT OF THE PROPOSED MODIFICATIONS

\begin{tabular}{|c|c|c|c|c|}
\hline $\begin{array}{l}\text { Site } \\
\text { Number }\end{array}$ & $\begin{array}{l}\text { Degree to Be } \\
\text { Affected }\end{array}$ & $\begin{array}{l}\text { Potential } \\
\text { Importance }\end{array}$ & Intensity & Recommendations \\
\hline 56 & 1 & 3 & 2 & Controlled Collections \\
\hline 65 & 1 & 3 & 3 & Testing \\
\hline 66 & 1 & 4 & 4 & No Work \\
\hline 67 & 1 & 2 & 2 & Excavation \\
\hline 68 & 2 & 4 & 8 & No Work \\
\hline 69 & 2 & 3 & 6 & Controlled Collections \\
\hline 70 & 2 & 3 & 6 & Testing \\
\hline 71 & 2 & 4 & 8 & No Work \\
\hline 72 & 2 & 4 & 8 & No Work \\
\hline 73 & 2 & 3 & 6 & Testing \\
\hline 74 & $I$ & 3 & 3 & Testing \\
\hline 75 & 2 & 3 & 6 & Testing \\
\hline 93 & 2 & 1 & 2 & Testing \\
\hline 94 & 3 & 4 & 12 & No Work \\
\hline 95 & 2 & 1 & 2 & Excavation \\
\hline 96 & 1 & 2 & 2 & Testing \\
\hline 97 & 2 & 3 & 6 & No Work \\
\hline 98 & 2 & 3 & 6 & No Work \\
\hline 99 & 2 & 3 & 6 & Controlled Collections \\
\hline 100 & 1 & 1 & 1 & Testing \\
\hline
\end{tabular}


TABIE IV (cont'd)

\begin{tabular}{|c|c|c|c|c|}
\hline Site & Degree to $\mathrm{Be}$ & Poterıtial & Intensity & Recommendations \\
\hline 101 & 2 & 4 & 8 & No Work \\
\hline 102 & 2 & 1 & 2 & Excavation \\
\hline 103 & 2 & 2 & 4 & Testing \\
\hline 104 & 2 & 2 & 4 & Testing \\
\hline 105 & 3 & 3 & 9 & No Work \\
\hline 106 & 3 & 3 & 9 & No Work \\
\hline 107 & 1 & 4 & 4 & Controlled Collections \\
\hline 108 & 3 & 1 & 3 & Excavation \\
\hline 109 & 2 & 3 & 6 & No Work \\
\hline 110 & 2 & 3 & 6 & No Work \\
\hline 111 & 2 & 3 & 6 & No Work \\
\hline 112 & 2 & 4 & 8 & No Work \\
\hline 113 & 2 & 4 & 8 & No Work \\
\hline 1.14 & 2 & 3 & 6 & Controlled Collections \\
\hline 115 & 2 & 4 & 8 & No Work \\
\hline 116 & 1 & 4 & 4 & No Work \\
\hline 117 & 1 & 4 & 4 & No Work \\
\hline 118 & 1 & 2 & 2 & Excavation \\
\hline 119 & 2 & 2 & 4 & Testing \\
\hline 120 & 2 & 2 & 4 & No Work \\
\hline 121 & 2 & 4 & 8 & No Work \\
\hline 122 & 2 & 3 & 6 & No Work \\
\hline
\end{tabular}


TABLE IV (cont $\left.{ }^{\prime} d\right)$

\begin{tabular}{lcccc}
\hline $\begin{array}{c}\text { Site } \\
\text { Number }\end{array}$ & $\begin{array}{c}\text { Degree to Be } \\
\text { Affected }\end{array}$ & $\begin{array}{c}\text { Potential } \\
\text { Importance }\end{array}$ & Intensity & Recommendations \\
123 & 3 & 3 & 9 & No Work \\
124 & 2 & 4 & 8 & No Work \\
125 & 2 & 2 & 4 & Testing \\
126 & 2 & 2 & 4 & Testing \\
127 & 2 & 3 & 6 & No Work \\
128 & 2 & 3 & 6 & No Work \\
129 & 2 & 3 & 6 & No Work \\
130 & 2 & 3 & 6 & No Work \\
131 & 3 & 4 & 12 & No Work \\
132 & 2 & 3 & 6 & No Work \\
1126 & & & & \\
\hline
\end{tabular}


Abbreviations Used

BTAS Bulletin, Texas Archeological Society

BTAPS Bulletin, Texas Archeological and Paleontological

Society (now Texas Archeological Society)

PA Plains Anthropologist

TJS Texas Journal of Science

Anderson, A. E.

1932 Artifacts of the Rio Grande Delta Region.

BTAPS 4: 29-31.

Campbe11, T. N.

1960 Archeology of the Central and South Sections of the

Texas Coast. BTAS 29: 145-176.

Cason, J. F.

1952 Report on Archaeological Salvage in Falcon Reservoir,

Season of 1952. BTAPS 23: 218-259.

Evans, G. L.

1941 Artifact Occurrence in the Second Terrace of the Rio Grande in Starr County, Texas. Bulletin of the Geological Society of America 52(12): 1998-1999.

Faulk, O. B.

1969 The Comanche Invasion of Texas, 1743-1836. Great Plains Journal 9(1): 10-50.

Hartle, D. D. and R. L. Stephenson

1951 Archeological Investigations at the Falcon Reservoir, Starr

County, Texas. Mimeographed Report to the Smithsonian Institution. 
Hester, T. R.

1969 Archaeological Investigations in Kleberg and Kenedy

Counties, Texas, in August, 1967. State Building Commission, Archeological Reports 15.

1971. Hunters and Gatherers of the Rio Grande Plain and the Lower Coast of Texas. Paper presented at the annual meeting of the Texas Academy of Science, Nacogdoches.

1974 A Bibliographic Guide to the Archaeology of Southern Texas. Journal of South Texas 1: 18-36.

in Chipped Stone Industries on the Rio Grande Plain of Texas. press TJS 26(1-2). To appear in 1975.

Hester, T. R. and F. A. Bass, Jr.

1974 An Archaeological Survey of Portions of the ChiltipinSan Fernando Creeks Watershed, Jim Wells County, Texas. Center for Archaeological Research, University of Texas at San Antonio, Archaeological Survey Report 4.

Hester, T. R. and T. C. Hill, Jr.

1971 An Initial Study of a Prehistoric Ceramic Tradition in Southern Texas. PA 16(52): 195-203.

1973 Prehistoric Occupation at the Holdsworth and Stewart Sites on the Rio Grande P1ain of Texas. BTAS 43: 33-75. Hester, T. R., L. D. White and J. White 1969 Archeological Materials from the Oulline Site and Other Sites in La Salle County, Texas. TJS 21(2): 130-165 
Hi11, T. C. Jr. and T. R. Hester

1973 A Preliminary Report on the Tortuga Flat Site: A Protohistoric Campsite in Southern Texas. Texas Archeology $17(2): \quad 10-14$.

Holdsworth, J.

1973 A Study of Modern Flora and Fauna in the Vicinity of the Holdsworth Site (41 ZV 14). BTAS 43: 65-73.

Hughes, J. T.

n.d. Proposal for Historical Studies in Connection With the Falcon Reservoir Area. Ms. on file, University of Texas at Austin.

Irwin, H. and M. Wormington

1970 Paleo-Indian Tool Types in the Great Plains. American Antiquity 35: 24-34.

Johnson, L., Jr.

1964 The Devil's Mouth Site, A Stratified Campsite at Amistad Reservoir, Val Verde County, Texas. University of Texas at Austin, Archaeology Series 6

Krieger, A. D.

1944 The Typological Concept. American Antiquity 9:271-288.

1956 Archeological Typology in Theory and Practice. In:

Selected papers of the Fifth International Congress of

Anthropological and Ethnological Sciences, Philadelphia. University of Pennsylvania Press.

Krieger, A. D., and J. T. Hughes

1950 Archaeological Salvage in the Falcon Reservoir Area: Progress Report No. 1. Mimeographed. Austin, Texas. 
McKern, W. C.

1939 The Midwestern Taxonomic Method as an Aid to Archaeological Culture Study. American Antiquity 4:301-313.

Newcomb, W. W., Jr.

1961 The Indians of Texas. University of Texas Press, Austin. Newton, M. B., Jr.

1968 The Distribution and Character of Sites, Arroyo 1os 01mos, Starr County, Texas. BTAS 38: 18-24.

Nunley, J. P.

1971a Sociocultural Units of the Southwestern Texas Archaic:

An Analytic Approach. Ph.D. Dissertation, Southern

Methodist University.

1971b Archaeological Interpretation and the Particularistic

Mode1: The Coahuiltecan Case. PA 16(54): 302-310.

Nunley, J. P. and T. R. Hester

1966 Preliminary Archeological Investigations in Dimmit

County, Texas. TJS 18(3): 233-253.

Ruecking, F. A. Jr.

1955 The Coahuiltecan Indians of Southern Texas and Northeastern Mexico. M.A. Thesis, University of Texas at Austin.

Sayles, E. B.

1935 An Archaeological Survey of Texas. Medallion Papers 16. Sellards, E. H.

1940 Pleistocene Artifacts and Associated Fossils From Bee County, Texas. Bulletin, Geological Society of America 51: 1627-1657. 
Shafer, H. J. and E. P. Baxter

1975 An Archeological Survey of the Lignite Project, Atascosa and McMullen Counties, Texas. Texas A \& M University, Anthropology Laboratory, Report 7.

Shafer, H. J. and T. R. Hester

1971 A Technological Study of Certain Bifacial Tools from

Southern Texas. Archeological Report, Texas Historical

Survey Committee 20.

Soil Conservation Service

1972 Soil Survey of Starr County, Texas. United States Department of Agriculture.

Suhm, D. A., A. D. Krieger, and E. B. Jelks

1954 An Introductory Handbook of Texas Archeology. BTAS 25.

Vigness, D. M.

1955 Indian Raids on the Lower Rio Grande, 1836-1837.

Southwestern Historical quarterly 59(1): 14-23.

Wakefield, W.

1968 Archeological Surveys of Palmetto Bend and Choke

Canyon Reservoirs, Texas. Texas Archeological Salvage

Project, Survey Reports 5.

Weir, F. A.

1956 Surface Artifacts from La Perdida, Starr County, Texas BTAS $27: 59-78$.

n.d. Site survey forms and notes on Starr County archeological sites. On file, Texas Archeological Research Laboratory, Austin. 
extensive, and buried under 5-10 $\mathrm{cm}$ of alluvium. The site may have been a temporary Gallery open camp.

41 SR 145. This is a Bower open camp site located on a hillslope overlooking the stream valley. The survey team observed an extensive occupational debris in the form of snails (often occurring in clusters or concentrations), burned rocks, flakes of chert and petrified wood, fragmentary bifacial and unifacial tools, and fragments of grinding implements. An intensive surface collection was made of the site. It is at least $100 \mathrm{~m}$ in diameter and extends into a rootplowed field.

$41 S R$ 146. The site is on both sides of a narrow arroyo in the west central part of the proposed 100 year flood pool. The area has been rootplowed, exposing a hearth (roughly $40 \mathrm{~cm}$ in diameter), a number of flakes, a core, and a piece of bifacially worked quartzite. The dimensions of the site are unknown.

\section{RECOMMENDATIONS}

It would appear that site 41 SR 145 is above the conservation pool level, but is within the 100 year flood pool. It is badly eroded and the intensive collection by the recent survey team should be sufficient. Site 41 SR 146 has already been badly disturbed by rootplowing and no further work is recommended. Site 41 SR 144 is very near the proposed dam location and will 
This page has been

redacted because it

contains restricted

information. 